\title{
The War Crimes CaSe of Károly Zentai AND the QUEST FOR HISTORICAL JUSTICE
}

\author{
RUTH BALINT ${ }^{1}$
}

More than 60 years after the Holocaust, attempts to bring the few remaining perpetrators of war crimes to trial are complicated by questions of memory and its relationship to the contemporary societies in which they are pursued. This is particularly evident in the case of Károly Zentai, a man wanted by Hungary since 2005 for extradition and questioning over the murder of a Jewish man in 1944. Zentai has lived in Australia since 1950, a country in which a number of perpetrators and collaborators found safe refuge after the war, and in which their presence was never sufficiently cause for any Australian concern. In Hungary, the complicity of the state in the Holocaust remains subject to historical denial, silenced by the myth of Hungarian victimhood in the war. For the historian, this case provides important insights into the historical links that evolved in the postwar period between Australia and Europe, and illustrates a wider debate about memory and history in the face of the 'perpetually remade past' $^{2}$

1 This is an extended and updated version of my article "The Ties That Bind: Australia, Hungary and the Case of Károly Zentai' in Patterns of Prejudice, vol 44, issue 2, 2010.

2 István Rév describes the way the events, ideas and the dead of the past are in a constant process of envisioning and remaking in Hungary; he posits 1989 as a particular moment in which millions lost their past and thus their future, leaving only what was unknown: 'At that point between the lost and the not-yetcomprehended, historians, politicians, and professional and amateur self-proclaimed experts offered ... to remake the world.' Rév, István (2009), Retroactive Justice: Prehistory of post-Communism, Stanford, Stanford University Press, 9. 
Given the distance to the event in temporal and, in the case of Australia, geographical terms, the role of memory is critical to understanding the contemporary context in which the case has been received in the two countries in which, at the time of mid-2012, it is still playing out. Since the French sociologist Maurice Halbwachs, himself a victim of the Nazis, first developed the notion of collective memory in the 1920s, the subject of memory has become an ever-expanding field of intensive scholarship and debate. Halbwachs' theoretical analysis highlighted the social dimensions of remembering and the way the present works to influence what is remembered in societies, and the institutions that embody the public acts of remembering. ${ }^{3}$ Since then, memory analysis has developed most significantly in relation to the Holocaust and World War II, in particular, the connection between historical memory and human rights. Holocaust memories, write Daniel Levy and Natan Sznaider, 'have evolved into a universal code that is now synonymous with an imperative to address past injustices (both legally as well as in commemorative terms). ${ }^{4}$

Halbwachs understood the link between memory, identity and human rights that is essentially the subject of this essay. For Halbwachs, as Jay Winter reminds us, collective memory is the binding agent of civil society. ${ }^{5}$ It is those associations and narratives about the past, shared and told by different groups of people, that tell them who they are and what they do. Memory, in particular the memory of past human rights abuses, also underpins the modern institutions of law and politics. For Levy and Sznaider, the universality of human

${ }^{3}$ Halbwachs, Maurice (1992), On Collective Memory, edited and translated by Lewis A Cosser, Chicago, University of Chicago Press.

${ }^{4}$ Levy, Daniel and Sznaider, Natan (2010), Human Rights and Memory, Pennsylvania, Pennsylvania State University Press, 4.

5 Winter, Jay (2012), 'Foreword: Remembrance as a Human Right', in Assmann, Aleida and Shortt, Linda, Memory and Political Change, London and New York, Palgrave Macmillan, ix. 
rights, a phenomenon that has emerged since the decade of World War II, 'necessitates a certain distance from the actual events that are being remembered'. ${ }^{6}$ They build on Jan Assmann's idea of a 'cultural mnemotechnique', which Assmann defines as 'the transformation of communicative, that is, lived and witness-embodied memory into cultural, that is, institutionally shaped and sustained, memory'. ${ }^{7}$ As the actual events of the Holocaust have begun to slip out of living memory, the iconisation of its memory is undergoing its own transformation. This essay is a contribution to understanding this transition.

\section{The politics of memory}

Since the fall of Communism, the question of 'which' past to remember, which to use in the forging of a post-Communist identity has galvanised nationalist societies in East-Central Europe. Randolph Braham believes that in Hungary the Holocaust has undergone a 'history cleansing process' since 1989, largely absolving Hungarian society and its political elites of responsibility for the destruction of two-thirds of its Jewish population. A reluctance to address the Holocaust past has been aided by a resurgence of antisemitism and the revival of the 'Jewish question', the forms of which have rehabilitated old stereotypes of the Jews as alien and unassimilable, and responsible for the evils of Communism. Preoccupation with the crimes of Communism has also been at the expense of a reckoning with the Hungarian Holocaust. ${ }^{8}$

${ }^{6}$ Levy and Sznaider, Human Rights and Memory, 15.

7 Ibid.

8 Tim Cole makes the point that the erection of a memorial in the late 1980s and another in the late 1990s to honour Raoul Wallenberg, the Swedish diplomat who led a massive rescue effort of Budapest's Jews in 1944 and disappeared into Soviet captivity after the war, was a political exercise designed to remember Wallenberg 'as a victim of 
This has represented a major setback to the project of historical understanding. Braham writes that although the number of populist champions of antisemitism and outright Holocaust denial is quite small in post-Communist Hungary, 'the camp of those distorting and denigrating the catastrophe of the Jews is quite large', and includes many respectable public figures: 'intellectuals, members of parliament, influential governmental and party figures, and high-ranking army officers' ${ }^{9}$ Even in its more moderate forms, these voices of historical revisionism have tended to assert that it was the Germans who committed the atrocities with the assistance of their Hungarian fascist accomplices, the Nyilas (the Arrow Cross party), while the rest-politicians, soldiers, gendarmes and citizens - were largely bystanders, or victims themselves. This remains a majority view. Within this equation, Zentai represents one of a 'few bad apples' rather than a cog in the Hungarian genocidal machine. His trial, should it ever go ahead in Hungary, is more likely to reinforce the mythology of Hungarian innocence rather than expose the complicity of the Hungarian regime in the mass murder of Hungarian Jewry.

Australia confronts an historical revisionism of a very different kind. Unlike East-Central Europe, where the atrocities took place, Australia has always seemed very far

\footnotetext{
"Soviet totalitarianism" rather than as a victor against Nazi "totalitarianism"'. His disappearance at the hands of the Soviets rather than his heroic rescue of thousands of Jews was highlighted (although other memorials, in the form of plaques and statues have since ensured the memory of his rescue efforts is preserved). See Cole, Tim (2003), Holocaust City: The making of a Jewish ghetto, New York and London, Routledge, 236-38.

9 Braham, Randolph (1999), 'The assault on historical memory: Hungarian nationalists and the Holocaust', East European Quarterly, vol 33, issue 4, Winter, 411-12.
} 
away from this history. ${ }^{10}$ It carries its own burdens when it comes to remembering World War II, in which the theatre of battle and its war crimes are fixed firmly in the Asia-Pacific. Yet from the moment authorities began the process of selection and recruitment for mass immigration in the Displaced Persons (DP) camps of occupied Europe in 1947, Australia became complicit in enabling those who had committed war crimes to escape retribution. ${ }^{11}$ To do so, Australian authorities participated in their own version of historical amnesia, and except for a brief period in the 1980s, deliberately ignored or downplayed the evidence of war criminals living in refuge in Australia for the next 60 years. Instead, the popular imaginary of the postwar period of immigration has privileged a narrative of rescue of Hitler's and Stalin's victims. When evidence to the contrary emerged, as it did quite frequently in the 1950s, it was buried by a combination of disinterestedness and an unwillingness to act, on the part of the authorities: a case of 'not our problem' ${ }^{12}$ If he is finally forced to face a Hungarian military court and found guilty, Zentai will likely represent a minor ripple in an otherwise unblemished record of Australian postwar immigration as a story of rescue and salvation of Europe's victims. Ironically, the real victims of war and the Holocaust were regarded as the least desirable of immigrants in Australia's practice of migrant selection and recruitment in

${ }^{10}$ In the geographics of the Holocaust, Australia is classified as a bystander nation.

${ }_{11}$ Aarons, Mark (2001), War Criminals Welcome: Australia, a sanctuary for war criminals since 1945, Melbourne, Black Inc, 17, 19.

12 Further, many of those who arrived in Australia with questionable pasts went on to gain influential positions in the political establishment. See Aarons, Mark (2001), War Criminals Welcome, Part Four, where he details the rise of former Nazis in the conservative Australian Liberal Party. 
the Displaced Persons camps of occupied Europe.

Australia does not have a strong record when it comes to prosecuting or extraditing war criminals. Yet seven years after the initial request was made for Zentai's extradition, it is still being fought in the courts, with the (then) Minister for Home Affairs, Brendan O'Connor, appealing against a decision by the courts to quash an earlier determination to extradite Zentai. This might suggest a shift in Australian attitudes, perhaps prompted by the Holocaust's increasingly 'global' presence in recent decades. It is impossible to imagine a history of the past century without the place names that have come to describe its most cataclysmic event-Auschwitz, Treblinka, Sobibor, Belzec, Majdanek and Buchenwald. There has likely been no other event in human history as extensively documented and analysed, performed and memorialised. ${ }^{13}$ Levy and Sznaider, speaking of the Holocaust 'memory boom', believe this has facilitated a new, global and cosmopolitan memory to aid a more moral, world-centred consciousness. ${ }^{14}$ Others have argued that the recent cultural

${ }^{13}$ Peter Novick describes a 'retrospective construction' of the Holocaust in the United States since the 1970s which he attributes to, among other things, the need to create a consensual symbol for Jewish identity (Novick (2000), The Holocaust in American Public Life, 7.) His analysis has since been criticised by Lawrence Baron, who argues that in the 15 years following the end of the war, American attempts to comprehend the Jewish tragedy were expressed through scholarly analyses, first-hand survivor accounts and mass media accounts. What was different was not a lack of American memory, but a different cultural framework within which it could be understood and articulated (Baron, Lawrence (2003), 'The Holocaust and American public memory, 1945-1960', Holocaust and Genocide Studies, vol 17, no 1, Spring, 62-88.)

${ }^{14}$ Levy, Daniel and Sznaider, Natan (2002), 'Memory Unbound: The Holocaust and the formation of cosmopolitan memory', European Journal of Social Theory, vol 5, no 1, 88. On the other side of the coin, however, this has meant a retreat into historical meaninglessness and 
obsession in the West with the Holocaust is contributing to a project of forgetting in other ways. Today, the proliferation of Holocaust imagery has not necessarily assisted with historical understanding, and evidence is that it can sometimes work against it, tending towards the trivialisation of the past, its ossification in public memory. ${ }^{15}$ The Holocaust has become a trope for things that often have nothing to do with it, and 'Auschwitz' is now a stylised, a-historical space in which to enact generic stories of pathos, drama and even comedy. Recently, too, there has been a new shift away from the theme of Jewish suffering towards a focus on the perpetrators. We have become far more interested in the human stories of Nazis than those of the victims. ${ }^{16}$

To make the leap from the growth of a more universal Holocaust-centred awareness to Australia's apparent newfound willingness to pursue and uphold Zentai's extradition is pre-emptive and probably misguided. Moreover, as was made clear in statements by $\mathrm{O}^{\prime}$ Connor to the press in 2009, Australia's decision to grant extradition

political conservatism. See Maier, Charles (1993), 'A Surfeit of Memory? Reflections on history, melancholy and denial', History and Memory, vol 5, no 2, Winter, 136-52.

${ }^{15}$ Huyssen, Andreas (1995), Twilight Memories: Marking time in a culture of amnesia, London and New York, Routledge, 255-56.

16 In Australia, this was most vividly demonstrated in 1995 with the awarding of the nation's highest literary honours for a novel that revived classic antisemitic discourses within the imaginative sphere of the Holocaust. The Hand That Signed the Paper won the nation's top literary award, the Miles Franklin, as well as the Vogel Literary Award for a manuscript by a writer under 35 . The author, calling herself Helen Demidenko and claiming to be of Ukrainian descent to enhance her credibility, was later discovered to be Helen Darville, of English parents. The book promoted the idea that Jews were partly responsible for the Holocaust. 
rests not on establishing Zentai's guilt or innocence, but in complying with Australia's extradition laws. ${ }^{17}$ The representation of Zentai's case in the mainstream media, meanwhile, does not support the theory that Australia has developed a more refined historical understanding of the Holocaust and the issues of justice or retribution. Rather, it resembles others in the way it is told, as the story of an old man who has led a largely blameless life in Australia pursued for some-thing that may or may not have happened a long time ago. ${ }^{18}$ Jane Cadzow's piece, published in 2008 in the Sydney Morning Herald, for example, under the title 'Another time, another place', capturing Australia's sense of remove from this history, and the idea that it has nothing much to do with the here and now. ${ }^{19}$

What makes this case of further interest is the fact that the crime Zentai is accused of has been known to authorities for over 60 years. The Budapest People's Court issued the warrant for his arrest in 1948 when his whereabouts in Allied occupied Germany were already known. Yet neither the Allies, under whose protection Zentai lived in Germany after the war, nor the Hungarian authorities who issued the arrest warrant, made any effort to bring him back to Hungary for

17 ABC News, Friday 13 November 2009.

18 The only exceptions to this simplistic packaging of what is a far more complex story have been a couple of articles published recently in an Australian magazine The Monthly, in which Hungarian writer György Vámos reviews some of the evidence, and Mark Aarons gives a brief account of Australia's tradition of apathy when it comes to punishing those who commit war crimes overseas but make their homes here: see Vámos, György (2009), 'Murder on Arena Avenue: is Charles Zentai guilty?', and Aarons, Mark (2009), 'Hideout', The Monthly, no 43, March.

${ }^{19}$ Cadzow, Jane (2008), 'Another Time, Another Place', Sydney Morning Herald, 14 June. 
trial. It would have been far simpler to do so. ${ }^{20}$ When he applied for passage to Australia while in the care of the International Refugee Organisation (IRO) as a DP, the Australian migration selection team was probably ignorant of the warrant. The Wiesenthal Centre, whose request to the Hungarian authorities initiated this recent case for extradition, claims it knew nothing of Zentai's case beforehand; but there is evidence that the Balàzs family had been trying to interest both the Wiesenthal Centre and the Hungarian authorities for decades.

In 2008 I travelled to Hungary where I reviewed the original evidence that initiated the request for Zentai's extradition. In Germany I uncovered documents relating to Zentai's journey through Allied occupied Germany, and his application for migration as a DP. These reveal other aspects of the case hitherto untold, and shed light on Australia's own contribution to the European process of forgetting, whereby through the postwar practice of immigration selection and recruitment in the Displaced Persons camps the crimes of the Holocaust were revised as purely German crimes, and antiCommunists regarded far more positively than anti-fascists, or even Jews, as potential 'New Australians'.

\section{The Holocaust in Hungary and the case of Peter Balàzs}

In 1944, the Jews of Hungary, numbering some 700,000, remained the most physically intact Jewish community in Europe. Close to 64,000 Hungarian Jews had already lost their

20 This doesn't appear to be an isolated case. Judit Molnár notes the case of the gendarme commander Gyözö Tölgyessy, whom the Hungarian People's Prosecution requested American authorities to extradite, but which never occurred (Molnár, Judit, 'Gendarmes Before the People's Courts', in Braham, Randolph and Chamberlin, Brewster S (2006) (eds) The Holocaust in Hungary: Sixty years later, Boulder, Social Science Monographs, 145). 
lives; 20,000 'alien' Jews had been sent across the border into Poland and shot at Kamenets-Poldolsk, and a majority of the rest were Jewish men killed when serving in labour battalions on the Ukrainian front. A series of severe anti-Jewish laws had also been implemented, restricting basic civil and socioeconomic rights. ${ }^{21}$ But the conservative government of Miklos Kallay (9 March 1942 to 22 March 1944) had stopped short of complying with Germany's demands for the deportation of Hungarian Jewry. ${ }^{22}$ The occupation of Hungary by Germany in March 1944 led to the implementation of the 'Final Solution' with a speed and efficiency unrivalled in other Nazi-occupied countries. Within a few short months, at a time when it was clear that the war was already lost, and when the realities of Auschwitz were public knowledge among the world's leaders, more than 437,000 Hungarian Jews were deported from the provinces to the death camps. This was only made possible with the wholehearted support of the Hungarian constitutionally appointed government of Döme Sztójay, the endorsement of the Regent of Hungary, Miklos Horthy, and with the assistance of local authorities. As Braham writes: 'With Horthy still at the helm, providing the symbol of national sovereignty, the Hungarian police, gendarmerie, and civil service collaborated with the SS in the anti-Jewish drive

${ }^{21}$ As Randolph Braham notes, the persecution and scapegoating of the Jewish population, and its enactment in legislation, was already a strong feature of Hungarian politics since 1919, with the installation of the counter-revolutionary regime of Miklos Horthy; the antiJewish campaign was institutionalised in 1938 with the first of the socalled anti-Jewish Acts of parliament, and legislation of major antiJewish laws. See Braham, Randolph 'Hungary', in Wyman, David S (ed) (1996), The World Reacts to the Holocaust, Baltimore and London, The John Hopkins University Press, 202-03.

22For a discussion of the politics of 1942 in relation to HungarianJewish policy considerations, see Karsai, Laszló, 'The Fateful Year: 1942 in the reports of Hungarian diplomats', in Braham, Randolph and Chamberlin, Brewster S, (eds) The Holocaust in Hungary, 3-16. 
with a routine and efficiency that impressed even the Germans.'23 By 1 June, the average daily number of Hungarian Jews being deported to Auschwitz was 20,000.24

By the end of July, virtually the only remaining Jews surviving in Hungary were in Budapest. In the month of July, 25,000 were deported to Auschwitz, at which point the government temporarily suspended deportations. In October, the fascist Arrow Cross party, under the leadership of Ferenc Szàlasi, was installed in government in a Nazi-orchestrated coup. The Arrow Cross embarked on a reign of terror, enacting frenetic killing sprees of the remaining Jews seeking refuge in the city. Thousands were arrested and shot and dumped into the Danube, and thousands more were shot or perished during a death march of 70,000 to Austria. The Arrow Cross reign lasted until Soviet forces liberated the city on 13 February 1945; during this time, those Jews who managed to stay outside of the ghetto, using false papers and not wearing a yellow star, had a slim chance of survival. Péter Balázs, an 18-year-old boy, was among those who chose the Jewish underground.

It was during this time that Zentai, a conscripted Hungarian Royal Army officer, was stationed at the Aréna Road military barracks in Budapest in 1944. Zentai's commanding officer was Bela Máder, and his fellow officer Lajos Nagy. After the war, they were tried for the murder of Péter Balázs and found guilty, Máder in 1946, Nagy in 1947. Máder was sentenced to forced labour for life; Nagy was given the death sentence, later commuted to life

${ }^{23}$ Braham, Randolph (1999), 'The Assault on Historical Memory: Hungarian nationalists and the Holocaust', East European Quarterly, vol 33, no 4, 413.

${ }^{24}$ Wiesel, Elie, 'Keynote Address', in Braham, Randolph and Chamberlin, Brewster S, (eds) The Holocaust in Hungary, xv. 
imprisonment. ${ }^{25}$ Evidence given at these trials prompted the Hungarian authorities to charge Zentai with the same crime; by that time, he was already in Germany living as a DP. These trials were part of the wave of war crimes trials held in Hungary in the immediate postwar period; approximately 27,000 people were sentenced by the Hungarian 'people's courts' for war crimes, crimes against the state or crimes against humanity, among them a number of senior government ministers. ${ }^{26}$ These also included local and county government officials, gendarmerie and military officers responsible for the expropriation, ghettoisation and deportation of the Jews of Hungary.

At his trial, Nagy told of how, under the orders of their commanding officer Bela Máder, Zentai went out on patrols regularly to perform identity checks and round up Jews for interrogation. According to Nagy, Zentai already knew Péter Balázs: in his statement after his arrest he told the police, 'Zentai told me that the boy and his family were old acquaintances of his'. ${ }^{27}$ The Zentai and Balázs families were both from Budafok, a small town on the outskirts of Budapest. The Balázs family were well known in their region as Jews and for their leftist sympathies; Dezsö Balázs, Péter's father, had his legal practice there until 1942 when the family moved into Budapest. Zentai, only a few years older than Péter Balázs, was apparently his 'Levente' instructor for a time in Budafok. ${ }^{28}$ Balázs was surviving on false identity papers, and defied a call-up order for a Jewish forced labour unit in April

25 Both men were released in 1956; Nagy went abroad.

${ }^{26}$ Karsai, László (2000), 'The People's Courts and Revolutionary Justice in Hungary, 1945-46', in Deák, István, Gross, Jan Tomasz and Judt, Tony (eds) (2000), The Politics of Retribution in Europe: World War Two and its aftermath, Princeton, Princeton University Press, 233.

27 Municipal Archives of Budapest, XXV.1.a, 3165/1947, People's Court Trial of Lajos Nagy.

${ }^{28}$ Levente was a military version of the Boy Scout movement. 
1944. On 8 November, Zentai recognised the boy on a Budapest tram and arrested him for not wearing the yellow star.

What happened afterwards, according to the evidence presented at Nagy's trial, is that between the hours of $3 \mathrm{pm}$ and $8 \mathrm{pm}$, Zentai and Nagy beat Balázs so badly that by $8 \mathrm{pm}$ he was dying. According to Nagy's evidence, they (Zentai, Máder and himself) saw that the boy was dying, and then went to an adjoining room and began drinking. In a macabre twist, Captain Máder decided to show off their handiwork to a number of other prisoners detained that night at Aréna Road. As a number of them testified at Nagy's trial, eight of them (some say six) were taken to Captain Máder's rooms, where one by one, they were shown a man lying on the floor covered by his own overcoat. His breath rattled, and it was clear that he was dying. 'Can you hear that music?' Sándor Révner stated that Máder asked him, when it came his turn to view the dying man. 'That's the way you will go too.' ${ }^{29}$ Each of the witnesses said they were told the same thing. The prisoners were then brought back into the room and forced to say the Hebrew prayer for the dead, 'and we said that prayer according to his instructions' ${ }^{30}$ The next day, all but one of them escaped. Each confirmed, as did other officers present that day, that the man lying on the floor, according to his photograph, was Péter Balázs.

I have before me the original court transcripts in which witnesses describe the brutalities they endured while they were detained at the barracks. There are various references to Zentai's regular participation in these beatings. Imre Zoltan testified that in 1944, while in Budapest as a forced labourer, he was arrested and taken to the barracks 'where at Béla

${ }^{29}$ XXV.1.a, 3165/1947, Lajos Nagy.

30 XXV.1.a, 3165/1947, Lajos Nagy. 
Máder's orders, Cadet Károly Zentai and Cadet Ferenc Érsek beat me up for hours with boxing gloves until I lost consciousness'. ${ }^{31}$ Ervin Barinkai, another soldier at the barracks, remembered seeing Zoltan 'gravely assaulted several times, especially by Cadet Sergeant Károly Zentai'. ${ }^{32}$ Another cadet, György Varsányi, stated that 'it was Cadet Sergeant Zentai who did the beatings, I saw that myself several times'. ${ }^{33}$

On the night in question, József Monori, another officer assigned to the barracks under Máder's command, reported that he heard, but did not see, the beating going on behind closed doors. He 'definitely' remembered Zentai, Nagy and Máder present. He went to bed, but was woken up at around $11 \mathrm{pm}$ and told to harness a horse and carriage: 'Nagy and Zentai brought down a corpse from the office, put it on the cart, and covered it with straw...Nagy sat on the driver's seat, Zentai beside him, and I sat on the side of the cart. Nagy was driving the cart. We drove along Aréna Road...down to the Danube...There Nagy and Zentai took the corpse and dumped it in the Danube. They waited a while to see if the corpse would come up but it sank.' Monori also stated that during the journey 'Nagy and Zentai were talking about how they should not have beaten the boy so hard'. ${ }^{34}$

These testimonies were taken before the warrant for Zentai's arrest, which was issued on 29 April 1948. After the warrant was issued, Máder, already a condemned man, stated that Zentai 'took part in patrols as well as in beating and maltreating Jews...He and 1st Lieutenant (Nagy) were always ready to volunteer to do the atrocities.' ${ }^{35}$ Imre Parázsló,

${ }^{31}$ XXV.1.a, 3165/1947, Lajos Nagy.

32 XXV.1.a, 3165/1947, Lajos Nagy.

${ }^{33}$ XXV.1.a, 3165/1947, Lajos Nagy.

34 XXV.1.a, 3165/1947, Lajos Nagy

${ }^{35}$ Municipal Archives of Budapest, XXV.1.a, 582/1946, People's 
another cadet, stated that the identity checks on Jews were 'mostly carried out by 1st Lieutenant Lajos Nagy and Ensign Károly Zentai accompanied by the worst imaginable beatings...Zentai hit hardest but Nagy was not far behind. They hit the Jews with fists, boxing gloves or sticks, kicked them, and I often saw these Jews beaten to a bloody pulp coming out of the office moaning and crying. Bela Máder knew about these tortures, indeed, he gave orders to them. ${ }^{36}$

Hungarian journalist György Vámos, referring to the 'unusual circumstances' of judicial practices in postwar Hungary, recently cautioned that witness testimonies relating to this case should be treated with care. He offers no detail beyond remarking that social justice, as opposed to merely criminal justice, was an important objective of the government at the time. ${ }^{37}$ This is largely true. The people's courts were driven less by legal concerns than by the desire for retribution and, in many cases, revenge. Confusion, insufficient preparation and political bias were rife during the major political trials, of which there were 14 between 1945 and 1946. 'The historical responsibility of the Hungarian principal war criminals is beyond question', wrote historian Laszlo Karsai. 'What is questionable, however, is whether the people's courts were sufficiently equipped to establish their criminal responsibility.' 38

Yet we must tread carefully in assessing minor trials such as those of Máder and Nagy. It is common in the West to

Court Trial of Máder Belá.

36 XXV.1.a, 582/1946, Máder Belá.

37 Vámos, György (2009), 'Murder on Arena Avenue: Is Charles Zentai Guilty?', The Monthly, March, 38.

38 Karsai, László, 'The People's Courts and Revolutionary Justice in Hungary, 1945-46', in István Deák et al, (eds) The Politics of Retribution in Europe, 248. 
dismiss all postwar trials in Hungary as Communist propaganda, but it was a little more complex than that. In the first place, the Communist Party did not entirely lead the fight against war criminals in the Hungarian courts in the immediate postwar years. The people's courts were party courts, in which representatives from across the anti-fascist political spectrum were chosen to take part. Delegates from the Bourgeois Democratic Party, the Social Democratic Party, the Communist Party, and the National Peasants Party, in addition to representatives from the right wing Independent Smallholders Party, were appointed people's judges. Later, delegates from the National Trade Union Association were also included. A professionally trained judge headed each of the courts, and a majority of votes determined a verdict. What determined the outcome of a particular trial or conviction was usually less the political sway of the parties involved in the process than the personal background and conviction of the judge. Moreover, the influence of the Communist Party only increased after 1947 in the courts, and only then did the number of trials dealing with war crimes or crimes against humanity significantly decrease. ${ }^{39}$

In the second place, condemning all postwar trials as 'show trials' also diminishes the contributions of the many Jewish survivors who did participate in what they saw as a way of achieving some kind of justice, and the importance of these trials at this time for gaining historical recognition. Braham writes that the 'tragedy of individual Jewish communities in Trianon Hungary was exposed in the war crimes trials held between 1945 and 1948 under the auspices of people's tribunals in Budapest and various county seats.' 40 Jews were heavily involved in the judicial process in Hungary

39 Karsai, László (2009), 'Esélyten, Reménytelen és Törvénytelen', Élet és Irodalom, vol 48, no 33, 13 August 2004. [Translated by Professor György Novak,].

${ }^{40}$ Braham, Randolph, 'Hungary', 208. 
after the war, a fact that is often overlooked in the antiCommunist revisionism of this history. This often took great courage: to give testimonies and to stand witness was an act of bravery for many Jewish victims of wartime atrocities. This is not to say that these trials were neutral or devoid of ideological bias; but they were often the only forum in which survivors could bear witness, and this should be taken into account when evaluating their testimonies. In trials specifically concerned with deportations or murder of Jews, the spectators at these proceedings also tended to be Jewish. Journalist Geza Losonczy was present at the joint EndreBaky-Jaross trial, the three men most directly responsible for the Hungarian Holocaust. He expressed his disappointment in the 'complete uninterestedness and indifference that the majority of the non-Jewish public manifests towards the case'. This was 'not a trial on behalf of the Jews' but 'a trial of the Hungarian nation against its executioners'. ${ }^{41}$

By 1948, official memory was writing the Jewish experience out of the war altogether as the Communist rereading of history began to take shape. Fascists became, before all other things, anti-Communists, their enemies Communists, even if their victims appeared otherwise. ${ }^{42}$ Hopes for restitution and indemnification were soon dashed in the new Communist Hungary, and any chance of rebuilding their communities was soon recognised to be futile. In all Soviet Bloc countries, despite an initial flourishing of scholarly discourse and literary publications addressing the tragedy of the Jewish genocide, as the Cold War deepened towards the end of the 1940s, discussion or acknowledgement of the uniqueness of Jewish suffering during the war largely

${ }^{41}$ Quoted in Karsai, László, 'The People's Courts and Revolutionary Justice in Hungary, 1945-46', 246.

${ }^{42}$ Rév, Istvan (2009), Retroactive Justice, 222. 
disappeared and the millions of Jews killed was revised as general war losses. ${ }^{43}$ During the Stalinist era of the 1950s, the Holocaust 'as a distinct historical phenomenon was usually downplayed, distorted or at best hardly referred to even in textbooks' ${ }^{44}$

Yet, following the uprising of 1956 and the subsequent liberalisation of Communism under the Kádár regime, and due to the increasing efforts of what was a comparatively large Jewish population for an East-Central European country $(80,000)$, there was a slight thawing of attitudes. ${ }^{45}$ Braham has argued that this period was one of increasing liberalisation, not only in economic policy but in cultural and artistic life, and that the Holocaust became an important subject for literary, artistic and scholarly attention among Jewish and Christian intellectuals. ${ }^{46}$ This should not be overstated; as Zsuzsanna Osvath observed, 'a few texts emerged that did not capitulate to the state-imposed ban on Jewish memory', and these 'recalled, repeated and expressed the events of the Shoah, bearing witness to the immensity of the trauma it created'. But the dominant trend in Hungarian literature and media throughout the 1960s, 1970s and 1980s 'either

${ }^{43}$ Braham, Randolph (1994), 'Antisemitism and the Holocaust in the Politics of East-Central Europe', Holocaust and Genocide Studies, vol 8, no 2, Fall, 145.

${ }^{44}$ Braham, Randolph, 'Hungary', 210.

45 This was momentarily thrown off course by Israel's Six Day War, which sparked a resurgence of antisemitism and anti-Zionism that also transcended Cold War borders. For example, Henry Rousso credits the 're-awakening of Jewish memory' in France during the 1970s, in particular Holocaust memory, in large part to intellectual and anti-Zionist condemnation of Israel after the Six Day War and the resurgence of antisemitism: see Rousso, Henry (1987), The Vichy Syndrome: History and memory in France since 1944, translated by Arthur Goldhammer, Cambridge, Harvard University Press, 132. 46 Braham, 'Antisemitism and the Holocaust', 148. 
suppressed or portrayed the Shoah as having only coincidentally Jewish features' ${ }^{47}$ As István Rév noted, the first state-sponsored Hungarian exhibition held at Auschwitz in 1965 articulated the official stance: of the 120 panels displayed, only ten related to the fate of the almost half a million Hungarian Jews who perished there, despite the fact that around one in three Jewish victims of Auschwitz were from Hungary, and not one of the panels related to the murder of thousands of Hungarian Roma. Instead, the exhibition, like official Hungarian memory, 'fell victim to the ideological war between Communists and anti-Communist Fascists' ${ }^{48}$

The end of Communism led to a resurfacing of antisemitic prejudice in the public arena, drawing in part on a deeprooted tradition of linking Jews with Communism in the popular historical imagination, in particular the high visibility of Jews in positions of leadership in the Communist regimes of 1919 and the post-World War II era. This antisemitic mythology ignored the fact that these leaders were almost all purged from their positions during the Communist era. Yet it has recently found new expression in a post-Communist preoccupation with 'the Jewish Question', a more extreme variant of which supposes that Jews used the postwar Communist regime for 40 years as payback against the Hungarians for the suffering they experienced at the hands of the Nazis.

In the first free elections of 1990, several politicians and prominent writers and journalists exploited these mythical connections. 'References to "alien" elements controlling the

47 Ozsváth, Zsuzsanna, 'Trauma and Distortion: Holocaust Fiction and the Ban on Jewish Memory', in Braham and Chamberlin, (eds) The Holocaust in Hungary, 339.

${ }^{48}$ Rév, Istvan (1999), Retroactive Justice, 228. 
media and playing a disproportionately prominent role in academia and the professions in the capital - a clear reference to Jews-were subtly interwoven with discussions of the political and socio-economic issues troubling the postCommunist society.' ${ }^{49}$ Since then, local anger at unemployment, economic downturns, inflation, impoverishment and government corruption has continued to find a convenient target in the Jewish population. Professor György Poszler, a member of the Hungarian Academy of Sciences, remarked on the recent turn in public discourse, in which the antisemitic voice, once tentative and sporadic, has become stronger and more frequent: 'The tone has positively degraded. It would be worth...comparing these texts with the phraseology and metaphors of the extreme right wing press of 60 years ago. ${ }^{50}$ As recently as April 2009, at a rally of the ultra right-wing Magdar Gárda (Hungarian Guard), there were open calls for physical violence against Jews. ${ }^{51}$

To some extent it would be possible to argue that the silence has deepened rather than thawed. The desire to absolve Hungarian responsibility in favour of German guilt is prevalent in government, the churches and other leading institutions. There are also those who continue to 'de-Judaise' the Holocaust, relativising Jewish loss in terms of all civilian and military losses incurred in the war. ${ }^{52}$ For Tony Judt, Hungary is the prime illustration of the difficulty of incorporating the destruction of the Jews into historical memory in post-Communist Eastern Europe. He uses the

49 Braham, 'Hungary', 214.

50 Anti-Semitic Discourse in Hungary in 2002-2003: Report and documentation, Desi, Janos, Gero, Andras, Szeszler, Tibor and Varga, Laszlo (2004) (eds), Budapest, B'nai B'rith Budapest Lodge, 185.

51 Email correspondence with Associate Professor Renata Uitz, Legal Studies, Central European University, 20 May 2009.

52 Braham, 'Hungary', 218. 
example of the immensely popular Terrorháza ('House of Terror'), the museum set up in Budapest after the fall of Communism to document the history of state violence and repression from 1944 to 1989 :

the Terrorháza's version of Hungarian history draws no distinction between the thugs of Ferenc Szalasi's Arrow Cross party, who held power there from October 1944 to April 1945, and the Communist regime that was installed after the war...The not particularly subliminal message here is that Communism and Fascism are equivalent. Except that they are not: the presentation and content of the Budapest Terrorháza makes it quite clear that, in the eyes of the museum's curators, Communism not only lasted longer but did far more harm than its neo-Nazi predecessor. ${ }^{53}$

Tim Cole agrees that the Terrorháza not only claims an equivalence between the victims of Fascism and Communism, but suggests that the Communist era was far more significant. The specific history of the Holocaust is subsumed within a more monolithic history that traces a story of universal Hungarian victimhood from 1944 to 1989, first at the hands of Nazi Germany and their foot soldiers, the Nyilas, and then the Communists. ${ }^{54}$ Yet across town, another museum is competing with this historical version of the Holocaust. The Budapest Holocaust Memorial Centre was created in 2004 on the site of the former ghetto in Pest. ${ }^{55}$ The Centre's permanent exhibition, From Deprivation of Rights to Genocide, is a comprehensive, state-of-the-art display of the history of the Hungarian Holocaust, and pays particular attention to the

53 Judt, Tony (2005), Postwar: A history of Europe since 1945, New York, The Penguin Press, 827-28.

54 Cole, Holocaust City, 246.

55 There is also another small Jewish museum located in the grounds of the Dohány utca (street) synagogue. 
relationship between the State and the main victims of racial persecution, namely Jews and Roma. The exhibition's timeframe begins in 1938, when the first Anti-Jewish Law was enacted. Extending the periodisation of this history in this way significantly challenges the version of history presented at the Terrorháza, which starts with the period of Arrow Cross rule in 1944, thus 'forgetting' or silencing the role played by the Hungarian state in implementing the Holocaust. Despite Cole's optimism that the short distance between the Holocaust Memorial Centre and the Terrorháza would make it possible to take in both museums in one day, the Terrorháza remains the far more popular option by locals and tourists alike. ${ }^{56}$

Istvan Hargittai is a professor of chemistry at Budapest Technical University and one of a few to have published in Hungarian his Holocaust experiences and the wall of silence that surrounds this history. He recalls that he and his generation grew up thinking 'it was the Germans' who were responsible for the Hungarian Holocaust. Members of the Arrow Cross were outsiders, so the theory went, unrepresentative of the Hungarian people. This myth prevails. Most Hungarians, he says, have lived since World War II as if Auschwitz never happened. ${ }^{57}$ The crimes of the Communist regime command the sphere of public debate over retribution and justice. The question of Hungarian complicity in the crimes against a significant number of its own people in World War II has yet to be asked.

Even those who might be expected to be supportive of seeing Zentai go to trial suspect that the effect is likely to be

56 Cole, Holocaust City, 247. Of the three or four times I visited in 2008, the Holocaust Memorial Centre was virtually empty except for myself and maybe two or three other visitors, while the House of Terror was very well patronised.

57 Interview with Istvan Hargittai, Budapest, 4 November 2008. 
detrimental to the Jewish cause. Hargittai predicts that the overwhelming image of Zentai will be that of a 'poor old man' who, if sentenced, will in all likelihood become a martyr of Jewish vengeance. Nevertheless, this does not mean, in Hargittai's view, that he shouldn't be tried. But there are others who feel that the negative impact such a trial is likely to have outweighs the argument for historical justice. ${ }^{58}$ Many intellectuals fear that a case such as this will strengthen antisemitism, particularly at a time when the rise of the extreme right is already threatening its resurgence. The fact that the Hungarian state has never acknowledged its own role in the destruction of Hungarian Jewry further complicates the issue. Without this acknowledgment, a trial such as this could become a tool for reinforcing the idea of a 'few bad apples' and the wider mythology of ordinary Hungarians' innocence and victimhood.

\section{Károly Zentai and the route to Australia}

Hungary's demand for Zentai's extradition has its own history. In 2004, Efraim Zuroff, the director of the Jerusalembased Wiesenthal Centre, visited Hungary to launch Operation Last Chance, which offered a reward of 10,000 euros to anyone with information leading to the arrest of war criminals. For Zuroff, such an operation was motivated by a universal obligation to the victims of the Holocaust; beyond that, Zuroff defended it as particularly significant in a country where acknowledgement of the Holocaust was still poor and where, in his view, the credibility of past trials was tainted in the popular imagination by their Communist associations. ${ }^{59}$

58 Conversation with Lázsló Czörc, Holocaust Memorial Centre, Budapest, 20 October 2008.

59 Zuroff, Efraim (2004), 'Nem reménytelen (Not hopeless)', Élet és Irodalom, 6 August. 
Operation Last Chance was not welcomed by a significant number of Jewish intellectuals in Hungary. A heated exchange erupted in the pages of Hungarian journal Élet és Irodalom (Literature and Life) between leading Holocaust historian László Karsai and Efraim Zuroff, in which Karsai attacked the operation as a 'blood money operation', labelling it unnecessary, unhelpful and 'without a chance'. ${ }^{60}$ According to Karsai, this strategy had no merit in the cause of historical justice:

For 10,000 euros, it occurs to someone that their dear old neighbour is possibly, very probably, an Arrow Cross (mass) murderer... Now try to imagine our 80-90 year old relative one day who is taken away by policemen, interrogated for hours, kept in remand in crowded, filthy cells perhaps for weeks or months only to be told before the court that his 95 year-old accuser is not so absolutely certain that he had seen him on the bank of the Danube in Pest, or in the brickyard at Békásmegyer in October or December 1944...I still insist that there is not much chance of finding real war criminals... and even less of having them convicted in Hungary today. On the other hand, the odds are very good for hundreds of innocent octogenarians being denounced in this country in the hope of 10,000 euro blood money. ${ }^{61}$

Not only would such cases be virtually impossible to prosecute so long after the event, but if anything, 'a Nazi hunting campaign with blood money in Hungary today could only result in the strengthening of anti-Semitism'. Karsai challenged Zuroff instead to look in places like Canada, the United States or Australia where most, he said, had ended up after the war. In his parting shot, he used the example of the Péter Balázs case to further illustrate his point:

On July 15, a Holocaust survivor gave me a ring. He told me

${ }^{60}$ Karsai, László (2004), 'Esélytelenek', Élet és Irodalom, vol 48, no 30, 23 July, translated by Professor György Novak, 2009.

${ }^{61}$ Karsai, László, 'Esélyten, Reménytelen és Törvénytelen'. 
that he had informed the Jerusalem Centre of the name and [Australian] address of the murderer of his brother. In the last 17 years the Centre has not even found him worthy of letting him know that the case has been shelved...(this) man...made it clear that he was not interested in the 10,000 euros, but wanted to see the murderer brought to court. ${ }^{62}$

Although Karsai did not mention the Balázs case by name, Zentai's extradition request was expedited soon after this exchange took place.

Presumably Zentai was never a big enough fish when Simon Wiesenthal was alive and his organisation was engaged in tracking down Nazis who had committed murder and brutality on a massive scale. The Balázs files held by the Holocaust Memorial Centre in Budapest attest to the long struggle of the family to resurrect the case and bring Zentai to trial. These papers tell a story of tenacity and despair, beginning with the small advertisement Péter's father, Dezsö, placed in a Budapest paper the day after Péter's disappearance, and subsequent advertisements looking for information about his son's whereabouts. 'My son, Péter Balázs, disappeared on 8 November. High reward for anyone bringing news of him' reads one, from 1 April 1945. ${ }^{63}$ Dezsö Balázs devoted the remaining 25 years of his life, until his death in 1970, to obtaining justice for his son's murder. His other son, Adam, inherited his father's cause. I have one letter, dated 20 November 1987 from Adam Balázs to a representative of the Wiesenthal Centre visiting in Budapest at the time, in which he includes a 1958 address for Zentai in Perth. Efraim Zuroff has since maintained that the first the Wiesenthal Centre heard of the Balázs case was in 2004, and it

62 Karsai, László, 'Esélyten'.

${ }^{63}$ Népszava, 1 April 1945. 
acted upon the information immediately. ${ }^{64}$

The story of how Zentai came to be in Australia is part of the history of Australia's first immigration program, in which tens of thousands of DPs were brought out on ships from the DP camps in Germany and Italy to Australia on its mass resettlement scheme. For many genuine refugees, Australia was 'the farthest place', far removed from the Europe of old race hatreds that had led to the concentration camps of World War II; for others, Australia was a country of last resort. Zentai's own application for refugee status, for example, lists Canada and Argentina as countries of preference for immigration. There is no mention of Australia. Contemporary observers were often struck by how comparatively easy it could be, if you were non-Jewish and 'fit', to get in to Australia when applications elsewhere had failed. Ron Maslyn Williams - on location in Germany in 1949 to make Mike and Stefani (1952)-wrote to his boss at the Commonwealth Film Unit, Stanley Hawes: 'As one intelligent DP put it to me "It is Australia or Siberia or starvation...Australia is the gambler's shot". Moreover, "quite literally, very many IRO officials regard Australia as a kind of modern Van Dieman's (sic) land where they can dump the people who constitute IRO's problem".'

The Australian authorities, for their part, counted physical attributes above all else as criteria for migration: one needed to be fit, preferably young and, more preferably still, fairskinned. Until 1960, humanitarian principles did not inform motives for assisted refugee migration-pragmatism did. Australia needed to expand its labour force and its population, and the only way that the government could sell its scheme of mass migration was by assuring its public that it remained committed to the principles of a 'White Australia'

${ }^{64}$ Email correspondence from Efraim Zuroff to the author, 3 May 2009. 
on which the Commonwealth was founded. Jews were especially unwelcome. Immediately after the war the government announced a humanitarian scheme to permit the arrival of concentration camp victims with Australian relatives; the scheme was met by antisemitic protest, and in response, the immigration minister Arthur Calwell introduced a quota system, in which only 25 percent of each ship carrying migrants could comprise Jews. These would be admitted only on the grounds of their potential contribution to Australia's economy, not on humanitarian grounds. 65

As Klaus Neumann has written: 'Suitable non-British settlers were young, educated and healthy and, ideally, possessed certain racial features. Australian selection teams preferred vigorous, flaxen-haired, fair-skinned and blue-eyed young men and women from the Baltic countries who did not or could not return to the Soviet Union.' These were to resemble Australia's 'own kind' as closely as possible. ${ }^{66}$ Beyond this, a philosophy of assimilation governed immigration policy and popular attitudes towards new arrivals. Immigrants, labelled 'New Australians', were expected to merge, quickly and quietly, into the Australian cultural and social landscape. This kind of thinking also implied, of course, that people's political pasts were as irrelevant as their cultural pasts - a slate wiped clean by the

${ }^{65}$ Australia was not alone in its pragmatic approach. Contemporary observers were struck by the commonalities that existed among the recruiting nations. Malcolm Proudfoot noted that 'in spite of all the protestations of sympathy, the pivot of national immigration policies in almost all the countries was strictly practical and closely related to domestic labour requirements.' See Proudfoot, Malcolm (1957), European Refugees: A study in forced population movements 1939-1952, London, Faber, 418.

66 Neumann, Klaus (2004), Refuge Australia: Australia's humanitarian record, Kensington, UNSW Press, 32-33. 
promise of Australian acculturation.

The Zentais ticked the right boxes: 'fit worker' is handwritten across both Károly and Rozsa's migration selection forms. ${ }^{67}$ In March 1949, Zentai, his wife Rozsa, their two sons born after the war, and Zentai's older sister, Julia, were at Tuttlingen in southern Germany's French zone, where they were interviewed and accepted by the Australian Migration Team for resettlement in Australia. Zentai's screening card twice states that he arrived in Germany on 9 March 1949, and that he had 'fled from the Communist Party'. His wife's card indicates the same information. The accompanying resettlement card from the IRO, which establishes their status as DPs, also states that Zentai and his wife were in Budafok between 1945 and 1949, and that their son Gabor was born in Budafok, Hungary, in 1946.

Except that he wasn't, and they weren't. Documents held by the International Tracing Service (ITS) tell a different story. The ITS, located in Bad Arolsen in Germany, is a massive storage house of SS records of the death camps, yet it also holds the records created by the Allies in the DP camps. Zentai's file includes his application for refugee assistance to the IRO, and lists his places of residence from 1938 onwards: in March 1945 he was already on his way to Dietersburg, Bavaria, where he arrived, according to the information he provided, on 19 April 1945 and remained until March 1948. A document dated 14 August 1946 confirms that he, his wife, his sister and his son, Gabor, born 26 February of that year, were in Dietersburg. His son Gabor is twice recorded as having been born in Arnstorf, Bavaria. Another, dated 15 July 1947, indicates that Zentai was temporarily in Kösslarn, in the district of Griesbach, also in Bavaria.

In his application for IRO assistance, a routine statutory declaration states that Karl Zentai was 'never a member of the 
Arrow Cross or any political party and never committed any atrocities'. It is signed by Zentai and three witnesses, dated 12 March 1948 at the Hungarian office (Ungarisches Büro) in Pfarrkirchen. A handwritten statement by an IRO officer concludes: 'On account of credibility of the statement of the Hungarian office and the witnesses he should be found eligible for refugee status with IRO assistance. Refuses to return home for the present regime there-no political freedoms.' ${ }^{68}$

None of these official records hint at the warrant for his arrest issued by the Budapest People's Court in April 1948, despite the fact that his whereabouts were well known to the Hungarian authorities. The warrant even lists an address, 'the American occupation zone in Germany, where his address at present is...Furth in Pfarrkirchen district with farmer Jakob Schneiderbauer' ${ }^{69}$ It appears that Zentai was able to make his way safely to Tuttlingen almost one year after the warrant was issued. Was the warrant ever communicated to the Allied Occupation Forces in Germany, and if so, why was it ignored? Did Zentai know about his warrant? The answers to these questions, of course, can only be speculative. Yet the inconsistencies in the records as to his whereabouts for the four years between 1945 and 1949 seem to indicate some kind of attempt to cover his tracks. In his recent interviews with the media, Zentai has never tried to deny that he was already living under the protection of the Allied Occupation Forces in Germany from 1945. Why then did he lie about his whereabouts in 1949? I contend that his decision was strategic: rewriting those four years in this way so as to convey that he was coming from Hungary in 1949 rather than

68 Zentai, Karoly, CM/1, ITS Nr 2-2647.

${ }^{69}$ Budapest People's Court, no 1948 Nü 3440/2, [Bálazs papers held in the Holocaust Memorial Museum, Budapest]. 
1945 distanced his decision to leave Hungary from the immediate aftermath of World War II, thus making it simpler to argue that he was 'fleeing the Communists', as so many other East Europeans were doing in the years of 1948 and 1949.

Moreover, as Zentai's case makes clear, the DP camps, and their route to Australia, could provide avenues of escape for those wishing to avoid retribution or exposure. It was well known to contemporaries that a number of collaborators and war criminals were hiding in the DP camps. G Daniel Cohen has examined the extensive technologies of screening and identification developed by the IRO, which took over from the United Nations Relief and Rehabilitation Administration (UNRRA) in 1947, to determine the authenticity of refugees and displaced persons. It was a daunting task, but according to IRO officials, 'of first importance in its work'. ${ }^{70}$ Refugees were now required to fill in numerous forms and questionnaires, yet as Cohen explains, if there was no apparent reason for exclusion, that is, if they seemed to fit the story they presented, they were not required to prove their right to be included as eligible. IRO officers received manuals that included sample cases and historical information to guide their decisions, and were taught how to detect untrue statements, yet in practice their mission to cleanse the system of ineligibles was often frustrated. Visitors reported that the 'right answers' to IRO questionnaires were circulating in the camps; further, it was clear to IRO officials that many simply destroyed their identity papers and made up new ones. Dates of displacement were frequently altered during interrogations to make their applications more plausible. Within the IRO, Cohen quotes, it was commonly believed that 'after many months of observation and listening, the DPs are told what to say and know how to craft an acceptable story leading to

${ }^{70}$ Cohen, G Daniel (2012), In War's Wake: Europe's displaced persons in the postwar order, Oxford and New York, Oxford University Press, 41. 
eligibility' ${ }^{71}$

Over one million people arrived in Australia under various immigration schemes by the end of the 1950s, and there are estimates that even in its earliest years, 4,000 to 5,000 Nazis may have found sanctuary there, most of them from East-Central Europe. ${ }^{72}$ As Konrad Kwiet notes, during the screening process they lied about their wartime activities, usually claiming to have been subjected to 'forced labour' or 'deportation to Germany'. 'In reality', he writes, 'many of them had actively enthusiastically assisted the Nazis. Their claims concealed "police work", military and Waffen SS service and participation in killing operations'. ${ }^{73}$

This should also be viewed in the context of a broader Allied retreat from the issue of denazification and punishment of wartime activities. Zentai was in Germany at the very moment that Europe's postwar memory was being moulded, by all sides, around the notion of German guilt, in which all responsibility for the war was made to lie squarely at the feet of the Germans. This focus on Germany meant the postwar status of other countries could be resolved. Thus Austria was retrospectively declared the 'first victim' of Nazi aggression and with Austria's innocence assured, the responsibilities of other non-German nationals in Europe were similarly eradicated. ${ }^{74}$ As the Cold War deepened, the

71 Cohen, In War's Wake, 42.

72 See Aarons, Mark and Loftus, John (1994), The Secret War Against the Jews: How Western espionage betrayed the Jewish people, New York, St Martin's Press.

${ }^{73}$ Kwiet, Konrad (2009), 'Historian's View - the War Crimes Debate Down Under', paper presented at the conference War Crimes:

Retrospectives and Prospects, Institute of Advanced Legal Studies, University of London, 19-21 February.

74 Judt, Tony (2009), 'The Past is Another Country: Myth and 
Allies were determined to avoid alienating Austria and Germany, and this meant removing attention from the past. 'In a process that would have been unthinkable in 1945', Judt wrote, 'the identification and punishment of active Nazis in German-speaking Europe had effectively ended by 1948 and was a forgotten issue by the early fifties' ${ }^{\prime}{ }^{75}$

IRO policy also reflected a softening towards those who previously may have been denied eligibility as collaborators. Ideological motives for assisting enemy forces, for example, became as important as their actions during the war; in other words, if someone had voluntarily enlisted in the German army because they wanted to oppose the Soviet regime, this was reason enough for inclusion. DP claims of antiCommunist sympathies and fear of Communist persecution began to carry as much, if not more, weight than claims of Nazi persecution. 'By 1950, refugees deemed "imposters" or "security threats" in the days of UNRRA were now offered the chance to emigrate to Australia or the North American continent. ${ }^{\prime} 6$

This strategic refocusing of attention away from the crimes of the past identified by Judt was enormously significant for the thousands, if not millions, whose wartime pasts were being reframed by a deliberate process of forgetting and denial, and whose identities were recast as refugees of an oppressive Communist regime. Australia's own role in this

Memory in Postwar Europe', in Deák, István et al, (eds), The Politics of Retribution in Europe, 296.

75 Judt, Tony (2009), 'The Past is Another Country', 297. Judt's statement is a slight exaggeration; though there was a marked decline in war crimes after 1948, preliminary war crimes' proceedings conducted by West German prosecutors numbered over 9,000 between 1949 and 1959.

76 Cohen, In War's Wake, 49. 
history was one of passivity and equally, one of denial. ${ }^{77}$ In the 1950s, protests by the Australian Jewish community over the migration of Nazis and their collaborators were eventually silenced by the continuing apathy and even hostility to their campaign. ${ }^{78}$ The politics and ideology of antiCommunism coloured government rhetoric and attitudes to the evidence of Nazi war criminals and collaborators living in Australia, and governed the state's failure to act. ${ }^{79}$ This was made explicit in the official response in 1961 to a request by the USSR for the extradition of an Estonian immigrant Ervin Viks, who was accused of murdering 12,000 Jews and Roma in the Tartu concentration camp. The Liberal government of Robert Menzies refused. In a speech defending the decision, Australian Attorney General Sir Garfield Barwick declared that against the 'utter abhorrence' felt by Australians against war crimes, 'there is the right of this nation, by receiving people into this country to enable men to turn their backs on past bitternesses and to make a new life for themselves in a happier community'. He concluded, in what has become an

77 As David Dyzenhaus has so aptly commented in another racial context (South Africa), the attempt to forget is not an unconscious process: 'it requires deliberate decisions from the vantage of one who does in fact remember'. See Dyzenhaus, David (1998), Judging the Judges, Judging Ourselves: Truth, reconciliation and the Apartheid legal order, Oxford, Hart Publishing, 92.

78 When the Jewish Council to Combat Fascism and Antisemitism reported the names of Nazi war criminals in Australia in the 1950s, the result was ASIO's investigation of that Council for 'Communist' activity, and not of Nazi criminals (Colin Tatz, personal communication).

79 Fraser, David (2010), Daviborshch's Cart: Narrating the Holocaust in Australian war crimes trials, Lincoln and London, University of Nebraska Press, 53. 
infamous phrase: 'the time has come to close the chapter' ${ }^{80}$

This directive to forget in order to create 'new lives' and a 'happier community' became a prevailing ethos in the next few decades, assisted by the fact that there was no legal framework established for extradition or prosecution of suspected war criminals. This changed briefly in the late 1980s when, under the Hawke Labor government, a special inquiry was set up to investigate allegations of Nazi war criminals living here, inspired largely by the forensic investigations of journalist Mark Aarons in a series of reports for ABC radio and television, which resulted in the Menzies Report. Controversial legislation was passed in parliament enabling Australian courts to prosecute suspects for war crimes (War Crimes Amendment Act, 1988) ${ }^{81}$. Most importantly, a Special Investigation Unit (SIU) was created within the federal Attorney General's department to investigate suspected war criminals. In its five short years of operation, there were 843 investigations, three individuals charged and tried in Adelaide, with no successful conviction. ${ }^{82}$ In 1992, the SIU was closed down, and responsibility for following up war crimes' accusations delegated to the federal police, who were either unwilling or unable to investigate them. It was, in Kwiet's words, 'a clear signal that the second chapter of the war crimes debate in Australia was closed'. During his brief tenure as chief historian for the SIU, Kwiet observed both the

${ }^{80}$ Fraser, David, Daviborshch's Cart, 57.

81 This statute evoked furious opposition from senior public figures: several senators, an archbishop, the head of the RSL, and at least three noted jurists. Even the Financial Review believed it would 'tear apart the fabric of Australian society'. Tatz, Colin (1997) 'Genocide and the Politics of Memory' in Genocide Perspectives I, ed Colin Tatz, Centre for Comparative Genocide Studies, 328.

82 See Fraser, Daviborshch's Cart, for an extensive discussion of the war crimes legislation in Australia and the trials of the three cases of Ivan Polyukhovich, Mikolay Berezowsky and Heinrich Wagner. 
negative, 'even damning' attitude that prevailed within the legal fraternity towards war crimes' legislation and the proceedings themselves; and the frequent indifference of the Australian public. He recalls:

In the public domain the war crimes debate had, in my view, little, if any impact on public awareness and memory... The public proceedings in Adelaide took place in front of empty galleries. Quite popular in the scant media coverage were references to the accused as 'nice neighbours' or 'old' and 'sick' pensioners. For the overwhelming majority of Australians, the news of the closure of the SIU went almost unnoticed. 83

David Fraser has also noted that the presence of unpunished perpetrators never became part of the cultural or political dynamic of Australian national identity or Australian values. ${ }^{84}$ Yet others have recognised that in spite of a lethargic community response to war crimes trials, these are important forums for producing cosmopolitan ideals of justice and human rights. They also affirm the role of history, in the form of evidence that 'things happened', in justice work and in the work of remembrance.

Although the legal framework was successfully developed by the SIU in the late 1980s, the resources for the investigation of people who have committed war crimes overseas have not been forthcoming and there have been no charges laid since. ${ }^{85}$

${ }^{83}$ Kwiet Konrad, 'Historian's View - the War Crimes Debate Down Under'.

${ }^{84}$ Fraser, Daviborshch's Cart, 310-11.

85 It is now the case that since 2002, when Australia amended its legislation to include war crimes, crimes against humanity and genocide as criminal offences in Australian law (Commonwealth Criminal Law, 2002), war criminals from conflicts prior to 2002 cannot be tried in an Australian court. 
The Wiesenthal Centre recently listed Australia as the 'only major country of refuge' and former diplomat Fergus Hansen, in a recent report compiled for the Lowy Institute, writes that Australia 'has inadvertently become a safe haven for war criminals'. This is certainly the impression Australia has been giving the world, and presumably its war criminals, for some time. Hansen notes that there are indications war criminals have come here from Afghanistan, Palestine, Sri Lanka, Nepal, Sierra Leone, India, Cambodia, Iran, Iraq, Chile, Lebanon, Nigeria, Bangladesh, the former Yugoslavia, possibly Rwanda and East Timor as well, among other countries. ${ }^{86}$

\section{The twilight of memory and the struggle for historical justice}

Zentai's appeal against his extradition to Australia's Federal Court in April 2008 failed, with Federal Court judge John Gilmour finding that there was no reason why Zentai should not be extradited to face trial. The court agreed to bail for Zentai on the grounds of ill health, and his lawyers took the case to the Minister for Home Affairs, O'Connor. This appeal failed, and Zentai was ruled fit to travel. This time Zentai's lawyers based the justification for their appeal on the argument that the offence for which Zentai is convicted did not constitute a war crime at the time it was committed. The implications of an argument such as this, although not new, are momentous, legitimising what was, in effect, a fascist regime at the time and putting forward the quite extraordinary idea that for Jews like Balázs, being beaten to death was somehow lawful. A similar argument was made during the Nuremberg Trials, in which the question of

86 Hansen, Fergus (2009), 'Confronting Reality: Responding to War Criminals in Australia', Policy Brief, Lowy Institute for International Policy, February, 3-4. 
whether the 24 German leaders ${ }^{87}$ should have to answer for actions rendered illegal after the fact-ex-post-facto-was put forward by the defence. The prosecuting lawyers never conceded this point, arguing that the charges were grounded in international law and what they called a common law of nations. Such an argument suggested that the accused had no idea they were acting illegally, an argument without merit in the minds of contemporary observers: murder is murder. The legality of the charge of war crimes was upheld at Nuremberg, and it is commendable that Federal Court judge John Gilmour resisted such logic today.

His lawyers successfully appealed the decision, taking it back to the Federal Court. In July 2010, Justice Neil McKerracher ruled that the Government had made an 'error of law' in agreeing to extradite him, and that the crime for which Zentai was charged was not an extraditable offence under the Extradition Act. Zentai returned home, but in 2011 the Federal Government returned to the High Court for another appeal, seeking a ruling on what constitutes a war crime. It is thought that such a ruling will have a significant impact on Australia's extradition regime.

Zentai has clearly led an exemplary life in Australia. He is the embodiment of the multicultural ideal, a man who worked, brought up a family here and settled quietly into the suburban landscape. It is not easy to watch a frail elderly man being hauled in front of the courts to face trial. He might, despite all the evidence, be innocent. There are powerful incentives to simply turn our collective back on this story and let the old man be. But are we also prepared to accept a statute of limitations on war crimes or crimes against

87 Initially 24 men were indicted, three were missing - Ley suicided, Borman disappeared, and Krupp (Sr) was deemed too infirm to stand trial. 
humanity? Is there a time when it is too late for justice? 'That the past slips into the oblivion of forgetting does not change its moral nature', writes Booth. 'The passage of time may dull our recollection of events, but it does not erase the (morally weighty) fact of their having happened nor the wrong involved in them.' 88

Mnemonic struggles over past wars and injustices have become common sites of battle over the legacies of the past in contemporary politics and law. How far the practice of retribution and punishment can generate reconciliation and acknowledgement is recognisably limited. Punishment, writes Jeffrey Olick, 'cannot be the ultimate measure of how a society has "dealt" with its past'. This was one of the lessons of Nuremberg, which despite its importance in forcing a certain truth to be told and for establishing moral and legal precedents had its costs as well, 'providing an alibi for an expertly equivocating population eager to lay the blame on a narrow "clique"'. ${ }^{89}$ As Booth writes, the trial of a perpetrator inevitably looks to individual accountability in its proceedings. 'In regimes where there was a gray area of collaboration and passive acquiescence or even support, that creates a very narrow focus... The co-responsibility of a people and state does not readily fit into the horizon of a courtroom proceeding, which looks for bloody hands that no one except the direct perpetrators will have. ${ }^{90}$

The question remains: will Zentai's extradition and trial promote the cause of historical justice? Or will it, rather, reinforce the dominant mythology of a 'few bad apples'? What is most fascinating, and disturbing, are the ways in

88 Booth, W James (2006), Communities of Memory, On witness, identity and justice, Ithaca and London, Cornell University Press, 160.

89 Olick, Jeffrey K (2007), The Politics of Regret: On collective memory and historical responsibility, New York and London, Routledge, 151. 90 Booth, W James (2006), Communities of Memory, 135-36 
which an affair of memory of this kind is able to be appropriated and subsumed by the dominant historical narrative, reinforcing rather than challenging historical myths. The danger is that what Zentai's case reveals about the past will be rewritten by the language of contemporary prejudices rather than illuminate those of history.

Andreas Huyssen has described our time as the twilight of memory. 'Twilight', he writes, 'is that moment of the day that foreshadows the night of forgetting, but that seems to slow time itself, an in-between state in which the last light of the day may still play out its ultimate marvels. It is memory's privileged time. ${ }^{\prime 91}$ As did Levi, Huyssen believes the struggle for memory is also a struggle for history. When we think of the Holocaust today, we often imagine our present time in terms of it being 'too late' for justice. But perhaps today, despite the risk of what I have outlined above, in this brief twilight of Holocaust time when victims and perpetrators are gradually leaving our world behind, we should be ensuring that these cases are told and not forgotten. Justice, not memory, is the antonym of forgetting, writes Booth. 'In other words, the imperative to remember is not the leaden voice of what has gone before, but rather it is the call of justice insisting on the irreversibility and persistence of what has been done, its claims on us which are neither diminished nor augmented by the extra-moral passing of time, and which call on us to bear these injustices in mind.' ${ }^{92}$ History's purpose is to give meaning to the present even as it seeks knowledge of the past; justice, or the attempt at it, however flawed and incomplete, belongs squarely within the historical project of understanding. A 1987 cartoon by Ben Sargent about the

${ }^{91}$ Huyssen, Andreas (1995), Twilight Memories: Marking time in a culture of amnesia, London and New York, Routledge, 3.

92 Booth, W James, Communities of Memory, 159-60. 
Klaus Barbie trial in France remains pertinent: 'It's been more than forty years', a younger man remarks. 'Why are we hunting down a bunch of pathetic old men just to prosecute them for...er...uh...well, you know...uh...whatever that stuff was they did...?' The older man replies: 'That's precisely why.' 93

As Huyssen writes, 'the inner temporality and the politics of Holocaust memory, however, even where it speaks of the past, must be directed towards the future. The future will not judge us for forgetting but for remembering all too well and still not acting in accordance with those memories' ${ }^{94}$ Zentai's case is not just about Zentai. The important question of a regime and a country that enabled, indeed encouraged, the murder of thousands of Jews like Péter Balázs, and a country that then gave murderers refuge and even prosperity is still to be addressed. It is about the legacy of both countries in the denial and silencing of a 'memory of offence', and a responsibility towards our present and their future.

93 Quoted in Sodi, Risa (1989), 'The Memory of Justice: Primo Levi and Auschwitz', Holocaust and Genocide Studies, vol 4, no 1, 101. ${ }^{94}$ Huyssen, Twilight Memories, 260. 